\title{
Examining school leadership effects on student achievement: The role of contextual challenges and constraints
}

\begin{abstract}
The present study examined indirect effects of principal leadership on the mathematics achievement of 254,475 15-year-old students from 10,313 schools in 32 OECD economies. Results showed that the students could be divided into three categories (Disadvantaged, Average, and Privileged) differing in levels of student SES and prior achievement, parental academic expectations, and access to school resources. Results also showed that principal leadership effects accounted for a greater proportion of between-school achievement variance for Disadvantaged vis-a-vis Privileged or Average students. In particular, instructional leadership had the largest positive effect on Disadvantaged vis-a-vis other students' achievement via the mediating variables of teacher autonomy and morale. Distributed leadership negatively affected the achievement of Disadvantaged but not other students. The negative effects of principal goal-setting were the largest while those of principal problem-solving were the smallest for Disadvantaged students. The study contributes to the literature by examining contextual influences on the leadership-achievement relationship.
\end{abstract}

Keywords: school leadership; contingency theory; principals; achievement; context 


\section{Introduction}

There is research evidence that school leadership is the second most influential factor, after classroom teaching, predicting student achievement (Leithwood, Day, Sammons, Harris, \& Hopkins, 2006). The salience of the variable has attracted much empirical investigation on how school leadership influences student achievement directly, indirectly, or reciprocally (Heck \& Hallinger, 2010; Hendriks \& Scheerens, 2013; Hitt \& Tucker, 2015; Robinson, Lloyd, \& Rowe, 2008), with an emerging consensus among scholars that leadership impacts student achievement via intervening school or classroom variables (Hendriks \& Scheerens, 2013). At the same time, there are some scholars who underscore the importance of examining leadership effects with regards to the context in which it is enacted (Hallinger, 2003; Hallinger \& Heck, 2011; Klar \& Brewer, 2013; Louis \& Robinson, 2012; Ten Bruggencate, Luyten, Scheerens, \& Sleegers, 2012; Urick \& Bowers, 2014; Warwas, 2015). However, few studies have systematically examined what contextual variables moderate leadership effects and how the leadership-achievement relationship is moderated. For example, previous studies focused primarily on student SES (Day, Gu, \& Sammons, 2016; Hallinger, Bickman, \& Davis, 1996; Hallinger \& Heck, 2011; Hallinger \& Murphy, 1986), student prior achievement (Day, Gu, \& Sammons, 2016; Heck, 1992), and teacher experience and qualifications (Hallinger et al, 1996; Hallinger \& Heck, 2011). However, there are other contextual variables such as school resource quality and even parental expectations that may moderate principal leadership effects on student achievement. Therefore, the purpose of the present study is to examine the moderating influence of different contextual variables (comprising student SES, prior achievement levels, quality of different types of school resources, 
and levels of parental expectations) on the relationship between school leadership and student achievement.

\section{Leadership functions}

There are different typologies of school leadership (e.g., instructional, transformational, distributed, integrated) leadership that are nonetheless characterized by a set of core leadership functions (Leithwood, Jantzi, \& McEtheron-Hopkins, 2006). The first leadership function is principals managing the teaching-learning program. There is an established evidence base espousing the need for principals to be competent instructional leader who can lead teachers to excel in teaching-learning (Hitt \& Tucker, 2015). The instructional leader is sometimes contrasted with the principal who gets the school involved in myriad activities that distract teachers and students from learning. The second leadership function is principals designing the organization to emphasize collaborative decision-making processes among different stakeholders. In particular, principals can distribute leadership roles among teachers so that the latter can participate in school decision-making and continuous improvement, thereby meeting teacher aspirations, needs, and efficacy, and enhancing their commitment to the school (Robinson et al, 2008). The third leadership function is principals developing an academic school vision and giving directions. This shared mission eventuates in a common organizational purpose in an otherwise potentially dynamic and overwhelming school environment, fosters teacher buy-in, translates into concrete short-term goals and performance expectations, and promotes organizational sharing of information and the strategic use of different sources of data (Latham \& Locke, 2006; Murphy \& Torre, 2015). The fourth and last leadership function is principals understanding and developing teachers. This function addresses individual 
teacher strengths and needs, inculcates teacher responsibility for continuous professional development, influences school instructional practices, encourages teambased collaboration, builds teacher professional learning communities (PLCs), and enhances school academic capacity (Leithwood, 2012). In particular, principals play a strategic role in teacher professional development by fostering a schoolwide learning environment, examining core values influencing school practices, and managing the knowledge developed within schools (Opfer \& Pedder, 2011). For example, they have to play an active role as a member in a schoolwide professional learning community (PLC) of teachers, enact policies and provide resources to support the PLC, enhance communication system among school staff, facilitate in setting expectations for the PLC, buffer teachers from external contingencies, and affirm teacher professional growth (Murphy, 2015).

\section{School processes}

The research to-date indicates that principals' impact on student achievement operates indirectly through mediating school processes (Hendriks \& Scheerens, 2013). Indeed, the four leadership functions can be argued to influence school processes such as teacher focus on student-centered pedagogies, teacher autonomy, and teacher morale which in turn influence student learning. For example, principal focus on teaching-learning and staff development may result in teacher empowerment (autonomy) that enables them to implement more focused instructional practices. Empowered teachers can experiment with student-centered pedagogies such as adapting academic standards to student needs or developing student socioemotional competencies (Louis, Dretzke, \& Wahlstrom, 2010). Principal focus on teachinglearning and development of organizational directions has the effect of strengthening 
the school culture that is premised on high teacher expectations in student learning (Murphy \& Torre, 2015; Sun \& Leithwood, 2015). When principals communicate these expectations to teachers, and support and monitor teachers in their achievement of these expectations, teachers will feel a heightened sense of work morale and accountability, thereby benefiting student learning (Leithwood, 2012; Timperley, 2011). Principal distribution of leadership responsibilities involves the building of supportive relationships with teachers so that the latter can in turn nurture facilitative relationships with students in class, maximizes teacher ownership of school decisionmaking, and nurtures formal and informal leadership that builds on diverse expertise (Ostroff, Kinicki, \& Tamkins, 2003; Spillane, 2006; Supovitz, Sirinides, \& May, 2009). The result is enhanced teacher morale and autonomy which benefits student learning.

\section{Contingency theory of leadership}

In addition to the predictive validity of indirect as opposed to direct leadership effects models, some researchers averred that leadership effects on student achievement are not a singular phenomenon; rather, leadership must be understood with respect to the different contexts in which it is enacted (e.g., Hallinger \& Heck, 2011; Klar \& Brewer, 2013; Tan, 2013; Urick \& Bowers, 2014; Warwas, 2015). More specifically, contextual variables may render leadership functions to be more effective in some environments than in others.

The contingency opportunities theory contends that the agency and effectiveness of leadership is contingent upon environmental opportunities and challenges that leaders are confronted with (Wasserman, Anand, \& Nohria, 2010). It is premised on Hambrick and Finkelstein's (1987) idea that managerial discretion is 
consequential on the actions that leaders undertake in response to different challenges. This theory unifies two schools of leadership thought - proponents of leadership agency arguing that leaders adapt organizational variables to their environments (Child, 1972), and advocates of the constraints view of leadership emphasizing challenges impeding leadership imperatives (Martin, 1992). These contextual factors comprise student characteristics (e.g., student socioeconomic status or SES, prior achievement), and school internal and external environments (e.g., school resource availability, parental academic expectations of schools) (Hallinger, 2003; Hallinger \& Heck, 2011; Klar \& Brewer, 2013; Louis \& Robinson, 2012; Tan, 2013; Warwas, 2015). These contextual factors are discussed next in the following section.

\section{Student SES and ability}

Student academic performance may be impeded by inadequate learning resources in impoverished homes (Hallinger, 2003; Klar \& Brewer, 2013). Academically weak students may suffer from low expectations from teachers and parents, or ineffective teaching from unmotivated teachers (Rubie-Dabies, 2007). Therefore, the learning of these students may benefit most when schools communicate high expectations of their learning (Sun \& Leithwood, 2015), when teachers employ student-centric teaching that builds on their unique strengths and addresses their areas for improvement, and when teachers with high morale are motivated to help these students. Conversely, academically competent students may be already highly motivated and independent learners (Valentine, DuBois, \& Cooper, 2004), and have devised effective learning strategies. They are less dependent on motivated teachers or student-centered pedagogies to achieve academic success. Therefore, the indirect effects of principal leadership via school processes such as teacher morale and focus 
on student-centered pedagogies are expected to benefit the achievement of lower SES students and students with lower prior achievement more than higher SES and highachieving students.

\section{School resource shortages}

Principals need to address challenges of resource constraints related to the shortages of qualified teachers and support staff, learning infrastructure, and other educational resources. In particular, the shortage of qualified teachers implies greater difficulties in implementing innovative, student-centered teaching-learning (Gray \& Behan, 2005). Shortage of support staff means fewer opportunities for students to access school learning facilities. Shortage of information technology access may necessitate didactic teaching with negative ramifications on student learning (Chang, Chin, \& Hsu, 2008). These different resource shortages compromise the realization of principals' learning plans for schools. To resolve this challenge, principals need to boost teacher morale and autonomy so that the latter feels a strong sense of pride and belonging to the school, and therefore be committed to work creatively with fewer resources to achieve high student achievement. Therefore, the indirect effects of principal leadership via school processes such as teacher morale and autonomy are expected to benefit the achievement of students in resource-poor schools more than students from resource-rich schools.

In schools with abundant resources, teachers are able to optimize teachinglearning and enable students to actualize their learning potential. To bring teacher performance and student achievement to the next level, principals can empower teachers to make expert decisions in work areas that they know best (TschannenMoran, 2009). Empowered teachers are better able to meet their achievement and self- 
actualization needs (Maslow, 1943), and create classroom climates that also empower and motivate students in their learning (Ostroff et al, 2003). Therefore, the indirect effects of principal leadership via school processes such as teacher autonomy are expected to benefit the achievement of students in resource-rich schools more than students from resource-poor schools.

\section{Parent expectations}

Challenges may also emanate from the neoliberal context of educational accountability (Ball, 2003; Lee, Walker, \& Chiu, 2012). For instance, parents may have high expectations that schools will deliver quality education for their children (Gordon \& Louis, 2009). High parent academic expectations may motivate principals to provide instructional leadership (Ladd \& Fiske, 2003; Lee et al., 2012), and provide them with the legitimacy to require teachers to work harder (Meyer \& Scott, 1992), thereby securing greater staff commitment (Scott, 1994; Suchman, 1995). However, high parental expectations may also encourage schools to focus on short-term gains (e.g., using drill-and-practice to let students improve their achievement scores) and detract schools from making professional decisions in the best interest of student learning (e.g., teaching students critical thinking skills) (Bottery, Ngai, Wong, \& Wong, 2007). Therefore, high parental expectations may either accentuate or moderate principal leadership effects on student achievement.

\section{Method}

\section{Participants}

Participants were school principals and students who participated in PISA 2012 (OECD, 2013). PISA 2012 measured 15-year-old students' proficiency in 
applying their knowledge and skills learned in reading, mathematics, and science to authentic problems. In addition, PISA also collected data from students regarding their educational experiences and attitudes, and from school principals about school contexts. These students were selected to represent the complete population of 15year-old students who were attending public or private schools in grade 7 or higher in 68 participating economies.

However, it could be argued that principals in economically developed societies are more ready to embrace the four different leadership functions as compared to less developed societies. This is because in these societies, education systems are more developed, and therefore more resources are available for principals to upgrade their professional knowledge and skills (Mourshed, Chijioke, \& Barber, 2010). Most citizens may also have achieved basic standards of education (Baker, Goesling, \& Letendre, 2002), and therefore aspire higher educational standards from schools in order to be competitive in the knowledge-based economies. These reasons exert pressure on principals to upgrade their professional knowledge and skills in order to develop effective schools (Newmann, King, \& Youngs, 2000). Therefore, principal leadership effects in the Organization for Economic Cooperation and Development (OECD) economies were examined in the present study. After deleting cases with missing values ( $1.73 \%$ to $5.50 \%$ for different variables), the final sample size involved 10,313 principals and 254,475 students from 32 economies. ${ }^{1}$ These economies comprised Australia, Austria, Belgium, Canada, Switzerland, Chile, Czech Republic, Germany, Denmark, Spain, Estonia, Finland, France, United Kingdom, Greece, Hungary, Ireland, Iceland, Israel, Italy, Korea, Luxembourg, Mexico,

\footnotetext{
${ }^{1}$ According to Cheema (2014), different methods of handling cases with missing values (e.g., listwise deletion or multiple imputation) yield comparable unbiased parameter estimates if the percentage of missing values is low. Therefore, listwise deletion of cases with missing values was used in the present study in view of the relatively low percentage of missing values.
} 
Netherlands, New Zealand, Poland, Portugal, Slovak Republic, Slovenia, Sweden, Turkey, and United States of America.

\section{Measures}

In PISA 2012, the key student achievement variable was mathematics. Students were not administered the complete set of test items, so PISA 2012 computed five plausible values (PVs) for each student in the subject. For each student, these PVs represented the estimated distribution of scores of students with similar responses to the assessment and background items. This study measured student mathematics achievement using the five PVs which were separately analyzed. The results across the PVs were then compared.

Principals responded to 21 items on their frequency of specific leadership behaviors using a six-point scale $(1=$ Did not occur, $2=1-2$ times during the year, 3 =3-4 times during the year, $4=$ Monthly, $5=$ Weekly, $6=$ More than once a week). The present study used the four Rasch leadership scales available in PISA 2012. The first scale (PInstruct) measured principal instructional leadership using data from four items. These items pertained to principals promoting teaching practices based on recent educational research, praising teachers whose students were actively learning, and highlighting to teachers the importance of developing student critical and social capacities. The second scale (PDistribute) measured principals facilitating teacher participation in leadership using data from three items. These items pertained to principals providing staff with opportunities to participate in school decision-making, engaging teachers in school continuous improvement, and asking teachers to participate in reviewing management practices. The third scale (PGoals) measured principals framing and communicating the school's goals and curricular development 
using data from four items. These items were related to principals using student performance results to develop school goals, aligning teacher professional development with school goals, ensuring that teachers work according to school goals, and discussing school goals with teachers at meetings. The fourth and last scale (PProblemSolve) measured principals solving classroom problems teachers faced using data from three items. These items were related to principals taking the initiative to discuss matters when teachers had classroom problems, paying attention to classroom disruptive behaviors, and solving problem together with teachers when the latter brought up classroom problems. In a way, PProblemSolve represents a form of professional development for teachers.

School teacher morale (TrMorale) was measured using PISA 2012's Rasch scale calibrated from principal responses to four items on their perceptions of teacher morale in their schools $(1=$ Strongly disagree, $2=$ Disagree, $3=$ Agree, $4=$ Strongly agree). These items asked about high teacher morale, work enthusiasm, teacher pride in the school, and teacher emphasis on academic achievement.

Teacher autonomy (TrAutonomy) was measured using PISA 2012's Rasch scale calibrated from principal responses on whether teachers had a considerable responsibility for 12 different tasks (Yes or $\mathrm{No}$ ). These tasks were related to selecting teachers for hire, firing teachers, stabling teacher starting salaries, determining teacher salary increases, formulating school budgets, allocating budgets, establishing student disciplinary policies, establishing student assessment policies, approving student admissions, choosing textbooks to be used, determining courses, and deciding courses to be offered.

School teachers' overall focus on students (TrFocus) was measured using PISA 2012's Rasch scale calibrated from principal responses on whether mathematics 
teachers were interested in trying new methods and teaching practices, whether there was a consensus among mathematics teachers on adapting academic standards to student levels and needs, and whether there was a consensus among mathematics teachers on the importance of developing student socioemotional competencies vis-àvis mathematics skills and knowledge $(1=$ Strongly disagree, $2=$ Disagree, $3=$ Agree, $4=$ Strongly agree .

Student SES backgrounds (e.g., parents' education, profession, and wealth) were measured using the economic, social, and cultural status (ESCS) Rasch scale computed by PISA 2012. This index was scaled so that a value of 0 corresponded to the average for all students in the sample.

Student prior achievement (PriorAch) was measured by student responses on whether they had ever repeated a grade at the primary, lower secondary, and upper secondary level using a three-point scale $(1=$ No, never; $2=$ Yes, once; $3=$ Yes, twice or more). It was coded 1 if students had repeated a grade in at least one level $(13.40 \%)$ and 0 otherwise $(86.60 \%)$.

Principals indicated the impact of resource shortages in 13 areas on the school's capacity to provide instruction $(1=$ Not at all, $2=$ Very little, $3=$ To some extent, $4=A$ lot ). PISA 2012 provided three Rasch scales calibrated from these responses. First, ShortTr measured school shortages in qualified teachers (four items). The quality of educational resources (QualEdRes) was measured from responses on six items regarding shortages of science laboratory equipment, instructional materials, computers for instruction, internet connectivity, computer software for instruction, and library materials (reverse coded). Quality of physical infrastructure (QualInf) was measured from responses on three items regarding shortages in school buildings, heating/cooling and lighting systems, and instructional space (reverse coded). 
The extent of parental academic pressure on the school (ParentExp) was measured using principal responses $(1=$ Pressure largely absent, $2=$ Minority of parents exerted pressure, $3=$ Pressure from many parents).

The means and standard deviations for the variables are summarized in Table 1.

Insert Table 1 here

\section{Procedure}

PISA 2012 was sponsored internationally by the OECD, and coordinated and administered internationally by the PISA international consortium, led by the Australian Council for Educational Research. All participating economies followed standardized procedures outlined in the technical standards and manuals provided.

\section{Results}

\section{Latent classes}

Mixture modelling (Muthen, 2001), a particular type of latent class analysis, was first employed to classify students into different latent classes based on a combination of six student and school contextual variables, namely ESCS, PriorAch, ShortTr, QualEdRes, QualInf, and ParentExp. Results showed that the sample could be classified into three latent classes according to model fit indicators and substantive meaning of the classes (Table 2). The first latent class (Disadvantaged) comprised students who had the lowest SES, who had the highest probability of having repeated a grade, who attended schools with the most severe shortage of teachers and the worst 
quality of educational resources and infrastructure, and whose parents were perceived to have the least academic expectations of schools $(n=24,882)$. In contrast, the third latent class (Privileged) comprised students who had the highest SES, who had the lowest probability of having repeated a grade, who attended schools with the least shortage of teachers and the best quality of educational resources and infrastructure, and whose parents were perceived to have the highest academic expectations of schools $(n=49,757)$. The second latent class (Average) comprised students who were straddled in between the Disadvantaged and Privileged students $(n=179,836)$.

Insert Table 2 here

\section{Hierarchical linear modelling (HLM)}

Two-level fixed effect HLM with restricted maximum likelihood estimation (Raudenbush \& Bryk, 2002) was next performed using SPSS 23 to examine the effects of principal leadership on student achievement. ${ }^{2}$ HLM was employed because of its advanced computational capability to handle the complex nested nature of the PISA data (students belonging to different schools), test for mean differences in dependent variables (student mathematics achievement), examine the relationship between variables measured at a higher and lower level (e.g., association between

\footnotetext{
${ }^{2}$ While HLM is perhaps the most commonly used multilevel methodology in the analysis of nested data in school effectiveness studies (e.g., Liu et al, 2015), some researchers use another technique multilevel structural equation modeling (SEM). However, HLM was used in the present study because the primary purpose was to compare the pattern of mediation of leadership effects among different latent classes of students (which HLM is capable of) and not the testing of measurement models or comparison of competing structural models (which SEM is designed for). Furthermore, the nested HLM models enabled the change in principal leadership regression coefficients before and after the mediating school variables were added to be compared. This comparison is essential in the test for mediation (Baron \& Kenny, 1986).
} 
school principal leadership and student mathematics achievement), account for the different sizes of units, and compute the proportion of explained variance at different levels (e.g., between-school variance in student achievement) (Dedrick et al, 2009).

The independent variables were rescaled by subtracting the grand mean (computed from the entire sample) from the respective raw scores for ease of interpretation and to minimize multicollinearity among the variables. After the rescaling, each HLM parameter represents the 'effect' of the respective variable for a student with values on the other variables that are each equal to the grand mean for the respective variable. Three different models were tested for the three latent classes of students separately:

- model a - baseline with no predictors;

- model b - level 2 random intercepts model with principal leadership variables (PInstruct, PDistribute, PGoals, PProblemSolve); and

- model c - levels 2 random intercepts model with the principal leadership variables and school process variables (TrMorale, TrAutonomy, TrFocus).

There is evidence that principal leadership effects were contingent on contextual variables if the (a) effects of principal leadership (models b), (b) effects of school process variables (models c), and (c) proportion of between-school student achievement variance explained by principal leadership and school process variables (models $\mathrm{c}$ - models a) differed across different latent classes of students. 


\section{Principal leadership effects}

Results (Table 3$)^{3}$ showed that principal instructional leadership was positively related to student achievement for all latent classes of students (Model b). However, the magnitude of the regression coefficients varied, with the strongest coefficients for Disadvantaged ( $\gamma=11.22$ to 11.74) and weakest coefficients for Privileged students $(\gamma=4.85$ to 5.27). Principal distribution of leadership responsibilities among teachers was negatively related to student achievement for Disadvantaged students ( $\gamma=-5.42$ to -4.51$)$ but not related to student achievement for other classes of students. Principal goal-setting was negatively related to student achievement for all classes of students, but the magnitude of the regression coefficients were the largest for Disadvantaged $(\gamma=-9.78$ to -8.93$)$ and smallest for Privileged students $(\gamma=-5.05$ to -4.81$)$. Principals solving teacher problems were negatively related to student achievement for Average $(\gamma=-11.45$ to -11.24$)$ and Privileged $(\gamma=-12.18$ to -12.00$)$ students, but was not significantly related to student achievement for Disadvantaged students.

\section{School processes}

Teacher morale and autonomy were positively related to student achievement while teacher focus on student-centered pedagogies was negatively related to student achievement for all latent classes of students (Models c). However, the magnitude of the regression coefficients varied among the three latent classes. Teacher morale had the strongest coefficients for Privileged ( $\gamma=11.44$ to 11.95) and weakest coefficients for Disadvantaged students $(\gamma=7.34$ to 7.97$)$. Teacher autonomy had the strongest coefficients for Disadvantaged students $(\gamma=14.99$ to 15.64$)$ and the weakest

\footnotetext{
${ }^{3}$ The pattern of results for MathPV2 to MathPV5 was similar to that for MathPV1. Therefore, only the detailed results for MathPV1 are presented in the article.
} 
coefficients for Privileged students $(\gamma=2.96$ to 3.38). Teacher focus on studentcentered pedagogies negatively affected student achievement most for Disadvantaged students $(\gamma=-12.59$ to -12.04$)$ and least for Privileged students $(\gamma=-10.86$ to -10.50$)$.

\section{Mediation}

Results showed that many of the principal leadership regression coefficients were significant predictors of student achievement in models b. However, they decreased in magnitude in models $\mathrm{c}$ when the process variables, which were significant, were entered into the model, thereby implying that the process variables partially mediated principal leadership effects (Baron \& Kenny, 1986). Some of the principal leadership coefficients for Privileged students even turned from significance in model b to insignificance in model c (e.g., PInstruct in Table 3), thereby indicating that the process variables fully mediated principal leadership effects (Baron \& Kenny, 1986). The proportion of between-school student achievement variance explained by principal leadership increased when the school process variables were included in models c. Furthermore, the variance explained in models c was the highest for Disadvantaged students and lowest for Privileged students. For example, the proportion of variance for MathPV1 explained increased from $2.45 \%$ to $12.87 \%$ for Disadvantaged students, from $3.47 \%$ to $10.60 \%$ for Average students, and from $4.09 \%$ to $9.87 \%$ for Privileged students.

Insert Table 3 here 


\section{Discussion}

The present study examines the influence of principal leadership on 15-yearold student mathematics achievement from a contingency opportunities perspective (Wasserman et al, 2010). This perspective recognizes that environmental factors may afford opportunities or conversely pose challenges for leaders, thereby impacting the contribution of leadership to desired outcomes. Mixture modelling and two-level HLM were used to analyze the PISA 2012 data on principal leadership behaviors, mediating school processes, student and school contextual factors, and student achievement involving 254,475 students and 10,313 principals from 32 OECD economies.

\section{Latent classes}

Results of mixture modelling showed that students in the sample could be classified into three substantively meaningful categories, namely Disadvantaged, Average, and Privileged. Disadvantaged students typically came from the lowest SES families, had parents with the lowest academic expectations, and attended the most poorly resourced schools. The double jeopardy from family and school eventuates in a pattern of poor past and future academic performance (Willms, 2010). In contrast, Privileged students typically came from the highest SES families, had parents with the highest academic expectations, and attended the most resourced schools. The rich family and school resources contributed to their strong academic performance.

\section{Comparison among latent classes}

When HLM was performed for the three categories of students, results showed that principal leadership effects varied according to these categories. The variation 
was evident in the pattern of regression coefficients for the principal and school process variables, and also in the proportion of between-school variance explained in the models. In particular, the proportion of student achievement variance explained was the largest for Disadvantaged and smallest for Privileged students. These results provided support for the argument that principal leadership effects on student achievement were contingent on environmental constraints and challenges.

\section{Instructional leadership}

The results also provided insights on the association between principal and school process variables, and student achievement. For Disadvantaged students, principal instructional leadership positively impacted student achievement via higher levels of teacher autonomy and to a lesser extent, teacher morale (Models b and c). This finding suggests that principals have the potential to contribute to the learning of these students most effectively by exercising instructional leadership via empowering teachers so that they can make the best instructional decisions in their professional capacities and feel motivated to address student learning needs.

Indeed, the positive relationship between principal instructional leadership, as compared to other leadership functions encapsulated in alternative leadership typologies such as transformational or distributed leadership, with student achievement (Models b) is consistent with findings reported in the literature (Leithwood, Patten, \& Jantzi, 2010; Robinson et al, 2008). The indirect effect of principal instructional leadership on student achievement via teacher variables as found in the present study is also consistent with results reported in some previous works (De Maeyer et al, 2007; Leithwood et al, 2010; Louis et al, 2010). For example, Leithwood and colleagues (2010) compared different pathways in which principals 
might affect student achievement and found that only principal knowledge of teaching-learning matters in the so-called Rational path (vis-a-vis principals influencing teacher emotions and predispositions in the Emotional path or principal management of the school in the Organizational path) contributed to student achievement. Furthermore, elements of school academic press comprising high expectations for student achievement, belief in students, encouraging students, and providing high-quality instruction to students (similar to what was measured in TrMorale in the present study) mediated the effects of principal leadership in Leithwood and colleagues' (2010) study. De Maeyer and colleagues (2007) reported that principal integrated leadership (of which instructional leadership as an integral component) had an indirect effect on fourth and sixth grader reading achievement via the mediating effect of school academic climate characterized by teacher consensual emphasis on academic achievement. The schoolwide focus on academic achievement is congruent with the measure of TrMorale in the present study. Louis and colleagues' (2010) study of US teachers reported a direct negative relationship between instructional leadership and student mathematics achievement. However, further investigation using structural equation modeling showed that the effects of instructional (and also shared) leadership were mediated by 'professional community' and teacher 'focused instruction' comprising the use of both didactic and constructivist teaching. The professional community variable included teacher shared values on student learning (aspects measured in TrMorale in the present study), and teacher collaboration and sharing in teaching (aspects also measured in TrAutonomy in the present study).

The finding that principal instructional leadership had the greatest effects on Disadvantaged students (vis-a-vis other student categories) is consistent with results 
reported in previous studies (Day et al, 2016; Hallinger \& Heck, 2011; Hallinger \& Murphy, 1986; Heck, 1992). For example, Hallinger and Murphy's (1986) study showed that principals in effective low-SES schools had greater control of instruction within the school, and were more task- than relationship-oriented in their instructional leadership than peers in effective, high-SES schools. Similarly, Heck (1992) found that principals in high-achieving high schools encouraged more discussions of instructional issues in schools, buffered teachers more from classroom interruptions, used test results more frequently to inform program improvement, had more systematic monitoring of student progress, and communicated instructional goals more effectively when compared to principals of low-achieving high schools. More recently, Hallinger and Heck (2011) identified three classes of schools in their study, and found that schools with lower initial student mean achievement levels but which experienced large improvements were those whose principals exercised greater levels of collaborative instructional leadership that focused on teaching-learning. Day and colleagues' (2016) mixed-method, longitudinal study of effective and improving English schools found that principals had higher levels of expectations in classroom teaching, emphasized student behavior and achievement, implemented more classroom observations, and coached ineffective teachers more when schools (with low student achievement levels) were in the beginning phases of their improvement journey. Principals then shifted their focus to student-centered learning and distributed leadership among teachers as schools experienced success in their improvement journey. However, the descriptive statistics in the present study (Table 1) also showed that the mean levels of principal instructional leadership, teacher autonomy, and teacher morale were the lowest for Disadvantaged students among all three categories of students. Therefore, principals leading schools with Disadvantaged students must 
recognize and reconcile this apparent paradox so as to raise the achievement of these students.

As for Privileged students, the results indicated that principal instructional leadership contributed to student achievement via the mediating influence of teacher morale, and to a lesser extent teacher autonomy (Models b and c). Interestingly, the mean levels of principal instructional leadership and teacher morale and autonomy were the highest for Privileged students, a finding that is consistent with that reported in Hallinger and colleagues' (1996) study which found that higher SES schools where parents were more involved had higher levels of principal instructional leadership and teacher expectations. However, the effects of principal leadership for Privileged students, although positive, were not as high as those for Disadvantaged students. This anomaly could be explained by the diminishing returns from school resources because Privileged students already had the opportunity to benefit from myriad learning resources in the first place (Chiu \& Khoo, 2005; Hallinger et al, 1996; Hallinger \& Murphy, 1986). For these students, the family instead of school might exert a greater influence on their achievement. For example, Privileged students may already be benefiting from strong home-school cooperation and high academic expectations from both home and schools (Hallinger et al, 1996; Hallinger \& Murphy, 1986). Furthermore, Privileged students may be more likely than Disadvantaged students to be studying in schools where the school mission focuses on high academic achievement (instead of basic mastery), where teachers translate their higher academic expectations to more effective teaching and quality homework, where the quality of academic curriculum and teaching is already high, and where there are more learning opportunities (Hallinger \& Murphy, 1986). Therefore, higher levels of 
principal instructional leadership may not necessarily eventuate in substantial improvement for Privileged as compared to Disadvantaged students.

\section{Distributed leadership}

The results also showed that principal distributed leadership (PDistribute) was negatively related to student achievement for Disadvantaged students but it was not related to student achievement for other classes of students (Models b). In a related vein, principal goal-setting (PGoals) was negatively associated with student achievement but for all categories of students (Models b). Principal problem-solving (PProblemSolve) was negatively related with student achievement but for Average and Privileged students (Models b). Similar counterintuitive results of negative principal leadership effects were reported in some previous studies (De Maeyer et al, 2007; Heck \& Marcoulides, 1996; Leithwood, Jantzi, \& McElheron-Hopkins, 2006; Leithwood et al, 2010; Louis et al, 2010; Ross \& Gray, 2006; Supovitz et al, 2010). For example, Leithwood and colleagues (2010) found that schools with teachers in school professional learning communities had lower levels of student achievement. Teachers in professional learning communities arguably enjoy less direct principal leadership (Wahlstrom \& Louis, 2008), less bureaucratic principal leadership (Tschannen-moran, 2009), and more distributed leadership (McLaughlin \& Talbert, 2007), and therefore these schools enjoy higher levels of distributed leadership as measured in the present study. Ross and Gray (2006) reported a negative, albeit insignificant, indirect relationship between principal transformational leadership and student achievement. Measurement of transformational leadership included principals encouraging teachers to set their own goals for professional learning, evaluate and refine their practices, and experiment with new practices. The variable is therefore 
also related to principal distributed leadership as measured in the present study. Louis and colleagues' (2010) study of US teachers reported that shared leadership in the school had a direct negative, albeit insignificant, effect on student mathematics achievement in regression analysis. This shared leadership had an indirect positive relationship with student mathematics achievement via the mediating processes of 'professional community' and 'focused instruction'. The professional community variable included teacher shared values on student learning (similar to that measured in TrMorale in the present study), and teacher collaboration and sharing in teaching (measured in TrAutonomy in the present study). 'Focused instruction' included a combination of didactic and constructivist teaching, the latter of which is similar to student-centered pedagogy measured in TrFocus in the present study. Leithwood, Jantzi, and McElheron-Hopkins' (2006) study of elementary schools (including those with needy, low-income, low-achieving students that were targets for school improvement) found a negative, albeit insignificant, relationship between school leadership (practices, school improvement planning, school improvement implementation) and student achievement (mean levels and growth). The school leadership processes included the involvement and empowerment of teachers, principals promoting teacher participation in school improvement, principals playing a facilitative role, teachers given the main responsibility for planning and implementation of school improvement, and principals providing resources to teachers to implement school improvement. These processes measuring teacher empowerment and principal provision of resources and support are similar to PDistribute and PProblemSolve as measured in the present study.

The negative relationship between PDistribute and achievement of Disadvantaged students, and the non-significant relationship for other classes of 
students implies that to improve the learning of academically weak, low SES students from resource-poor schools, it may be more effective for principals to take on a more directive role in high-level strategic decision-making and allow teachers to focus on teaching-and learning. At the same time, principals can empower teachers to make more 'local' decisions in professional matters (teaching-learning) involving students, teachers, or school budgets as measured by TrAutonomy. This approach is consistent with the implications from Hallinger and Murphy's (1986) study contrasting the levers of influence for different types of SES schools. It appears to matter less whether leadership is distributed for academically competent students who come from advantaged families or who attend resource-rich schools. The negative relationship between PDistribute, PGoals, and PProblemSolve and student achievement is further discussed in the following paragraphs.

\section{Goal-setting}

PGoals was negatively associated with student achievement for all categories of students (Models b). This finding is consistent with recent meta-analytic evidence that goal-setting or its two main constituents, namely developing shared goals and having high performance expectations, was not significantly related to student achievement (Sun \& Leithwood, 2015). However, a close examination of the items used to measure this variable in the PISA questionnaire indicates two possible reasons why PGoals was found to be negatively related to student achievement.

First, Murphy and Torre (2015) underscored the importance of setting challenging, achievable goals that apply to all students. However, PGoals as measured in PISA 2012 included principals using test results to inform goal-setting, but it is not clear if substantively and adequately challenging goals are set for the different 
categories of students varying in prior achievement levels among other background characteristics. Second, the PGoals items alluded more to a directive principal leadership that sought to align teacher efforts with school goals than to a collaborative goal development process promoting teacher goal ownership and consensual understanding. Taking reference from one of the most commonly used instrument of principal leadership, Principal Instructional Management Rating Scale (Hallinger \& Murphy, 1985), effective school goal-setting must go beyond principals aligning teacher work to include the incorporation of staff input, translation of school goals into classroom objectives, visible displays of consensual goals in the school, clear staff responsibilities, and clear communication of goals to students. Indeed, it is not sufficient for principals to align school processes with goals or to merely discuss the goals during meetings, as measured in PGoals. Rather, the goal development process underlining staff ownership and understanding of the goals; and principals displaying optimism and motivating staff to work toward challenging goals is as, if not more, important for translation into improved student learning (Murphy \& Torre, 2015; Sun \& Leithwood, 2015). Therefore, higher scores on PGoals may indicate a more directive style of principal goal-setting that may adversely affect teacher morale and autonomy. Indeed, the finding that the negative association between PGoals and student achievement was the greatest for Disadvantaged students is not unexpected given that teacher morale and autonomy were the lowest for this category of students.

\section{Problem-solving}

As for PProblemSolve, this variable measured the incidence of principals solving classroom problems that teachers encountered. Given competing demands, principals who spent time reacting to teacher problems and helping the later to solve 
the problems would have less energies to engage in other leadership functions that contribute to student achievement (e.g., instructional leadership) (Ten Bruggencate, Luyten, \& Scheerens, 2010). Therefore, it is not surprising to find a negative relationship between principal problem-solving and student achievement. In particular, the results showed that the magnitude of the negative association between the two variables was the smallest for Disadvantaged students (Models b). This negative association might also reflect the compensatory behavior of principals toward demoralized teachers struggling with classroom problems, given that the level of PProblemSolve was the highest, while the level of TrMorale was the lowest for this category of students (Table 1). Another possible reason explaining the smaller negative relationship between PProblemSolve and Disadvantaged student achievement is that principals for these students might be more competent problemsolvers than principals for other categories of students in the sample. Data for this assertion came from the higher mean levels of PProblemSolve for Disadvantaged visa-vis other students (Table 1). These more competent principals are more effective in problem-solving because their approach is guided by concern for student learning, they tend to use more well-conceived strategies when they encounter problems, they collect relevant information to inform their problem-solving, and they consult widely to arrive at the best solution. In contrast, less competent principals approach problems to maximize their own interests, are easily overwhelmed by problems, rely on assumptions in problem-solving, and are more concerned with patronizing parents (Leithwood \& Stager, 1989). 


\section{Focus on student-centered pedagogies}

Finally, the negative finding pertaining to the relationship between teacher focus on student-centered pedagogies (TrFocus) and student achievement (Models c) warrants discussion. In particular, it is interesting to note that the level of TrFocus was not particularly high for Disadvantaged students among the three classes of students but yet it negatively affected student achievement most for Disadvantaged students. The finding implies that teacher moderation of their expectations to cater to individual student needs, especially for lower ability Disadvantaged students, and the development of non-cognitive instead of cognitive capacities in these students (as measured in TrFocus) may have contributed to the negative relationship between TrFocus and student achievement. However, this does not mean that teachers should not focus on student-centered pedagogies as academic achievement comprises only one dimension of learning outcomes. Student-centered pedagogies may promote critical thinking and socioemotional capacities in students. These learning outcomes are less quantifiable but nonetheless important attributes needed in knowledge-based economies (Ananiadou \& Claro, 2009).

\section{Conclusion}

In summary, premised on the contingency opportunities perspective (Wasserman et al, 2010), the present study contributes to the school leadership literature in three ways. First, it addresses school leadership scholars' call for attention to the complex context of schools and the use of multilevel analytical techniques appropriate for the nested data employed in leadership effectiveness studies (May, Huff, \& Goldring, 2012). It presents empirical evidence on the utility of examining the effects of principal leadership in the light of external challenges and internal 
school constraints on student achievement. In particular, the present study extends previous scholarship by examining a wide spectrum of core principal leadership functions, instead of a subset of leadership practices (e.g., Heck, 1992; Hallinger et al, 1996; Hallinger \& Heck, 2011; Day et al, 2016), that constitute a more comprehensive measure of complex school leadership behaviors. The present study also analyzed multinational as opposed to single country data employed in many prior studies (e.g., Day, 2009; Day et al, 2016; Hallinger et al, 1996; Halllinger \& Heck, 2011; Halllinger \& Murphy, 1986; Heck, 1992), thereby increasing the probability of generalization for the findings reported.

Second, the study provides insights on the types of environmental challenges that moderate the leadership-achievement relationship. These challenges comprise student SES and prior achievement, school resource shortages, and parental expectations. In particular, the present study is the first to make substantively meaningful classification of students based on these different student and school contextual factors. In contrast, many previous leadership studies focused primarily on student SES, student prior achievement, and teacher quality (Day et al, 2016; Hallinger et al, 1996; Hallinger \& Heck, 2011; Hallinger \& Murphy, 1986; Heck, 1992). The present study is also among a small handful (e.g., Hallinger \& Heck, 2011) to systematically profile students based on myriad contextual factors using mixture modeling, a latent class analytical technique.

On the whole, results of the present study indicated that when compared to students from more advantaged backgrounds, the learning of disadvantaged students benefited from the presence of strong principal instructional (as opposed to distributed) leadership, and to a lesser extent, principals who supported teachers to solve classroom problems. These findings are reminiscent of those reviewed and 
summarized by Edmonds (1979). More specifically, Edmonds (1979) contrasted the principal leadership practices, among other school variables, in effective versus ineffective schools and concluded that effective schools were characterized by more assertive principals who emphasized instruction and the evaluation of school effectiveness over teacher collegiality. The findings of positive relationship between principal instructional leadership and student achievement for all students, and negative relationship between distributed leadership and student achievement (albeit for Disadvantaged students only) in the present study support Edmonds' (1979) assertions. Third, the study builds on the existing knowledge base expounding the indirect- over direct effects model of leadership. Given the complex pattern of influences involving principal leadership, school processes, internal and external contextual factors, and student achievement as shown in this study, it is useful for principals to take heed of the interrelationships between school processes and the environment in their leadership (Hendriks \& Scheerens, 2013; Menzias, 1995). For example, results of the present study suggested that principal leadership effects, particularly for instructional leadership, on student achievement were mediated via processes such as teacher morale and autonomy. Therefore, principals can empower teachers so that the latter can make the best professional decisions in teachinglearning to improve student achievement. This empowerment will also boost teacher morale which may contribute to student achievement.

Notwithstanding the contributions of the findings, the cross-sectional nature of the data in this study precludes any definitive claims of causation between principal leadership and student achievement. Future research using longitudinal data can investigate the causal paths alluded to in the present study, and unravel further explanations for the moderating effects of various contextual variables on the 
leadership-achievement relationship. A second limitation of the study arises from the self-reported perceptions of leadership behaviors by principals. While it is principal agency that generates leadership actions, and their own perceptions are therefore useful sources of information (Leithwood \& Jantzi, 2008), it is also acknowledged that principal self-reports may be inflated as compared to teacher-reports of principal leadership behaviors. Therefore, future studies can use teacher-reported principal behaviors and examine the moderating effects of environmental challenges on the leadership-achievement relationship. A third limitation arises from the use of predesigned measures in the PISA data, particularly the principal leadership and teacher classroom measures. Therefore, future studies can collect more comprehensive observational, interview, or survey data on the four core principal leadership functions, especially for goal-setting and teacher professional development, and for teacher classroom practices such as teachers maximizing student learning time in class, teachers collaborating to improve the academic curriculum, teacher participating in professional development to improve their instructional practice, and teachers refining their instructional practice (see Heck \& Hallinger, 2014). 


\section{References}

Ananiadou, K., \& Claro, M. (2009). 21 st century skills and competences for new millennium learners in OECD countries. OECD Education Working Papers, No. 41. OECD Publishing. Retrieved from http://www.oecd.org/officialdocuments/publicdisplaydocumentpdf/?cote=ED U/WKP(2009)20\&doclanguage $=$ en

Baker, D. P., Goesling, B., \& Letendre, G. K. (2002). Socioeconomic status, school quality, and national economic development: A cross-national analysis of the "Heyneman-Loxley Effect" on mathematics and science achievement. Comparative Education Review, 46(3), 291-312.

Ball, S. J. (2003). The teacher's soul and the terrors of performativity. Journal of Education Policy, 18(2), 215-228.

Baron, R. M., \& Kenny, D. A. (1986). The moderator-mediator variable distinction in social psychological research: Conceptual, strategic, and statistical considerations. Journal of Personality and Social Psychology, 51(6), 11731182.

Bottery, M., Ngai, G., Wong, P. M., \& Wong, P. H. (2007). Different contexts, different problems? Comparing the views of English headteachers and Hong Kong principals. Management in Education, 21, 14-18.

Chang, I.-H., Chin, J. M., \& Hsu, C.-M. (2008). Teachers' perceptions of the dimensions and implementation of technology leadership of principals in Taiwanese elementary schools. Educational Technology \& Society, 11(4), 229245.

Cheema, J. R. (2014). A review of missing data handling methods in education research. Review of Educational Research, 84(4), 487-508. 
Child, J. (1972). Organizational structure, environment and performance: The role of strategic choice. Sociology, 6(1), 1-22.

Chiu, M. M., \& Khoo, L. (2005). Effects of resources, inequality, and privilege bias on achievement: Country, school, and student level analyses. American Educational Research Journal, 42(4), 575-603.

Day, C. (2009). Building and sustaining successful principalship in England: The importance of trust. Journal of Educational Administration, 47(6), 719-730.

Day, C., Gu, Q., \& Sammons, P. (2016). The impact of leadership on student outcomes: How successful school leaders use transformational and instructional strategies to make a difference. Educational Administration Quarterly, 52(2), 221-258.

Dedrick, R. F., Ferron, J. M., Hess, M. R., Hogarty, K. Y., \& Kromrey, J. D., Lang, T. R., Niles, J. D., \& Lee, R. S. (2009). Multilevel modelling: A review of methodological issues and applications. Review of Educational Research, 79(1), 69-102.

De Maeyer, S., Rymenans, R., van Petegem, P., van den Bergh, H., \& Rijlaarsdam, G. (2007). Educational leadership and pupil achievement: The choice of a valid conceptual model to test effects in school effectiveness research. School Effectiveness and School Improvement, 18(2), 125-145.

Edmonds, R. (1979). Effective schools for the urban poor. Educational Leadership, $37(1), 15-24$.

Gordon, M. F., \& Louis, K. S. (2009). Liking parent and community involvement with student achievement: Comparing principal and teacher perceptions of stakeholder influence. American Journal of Education, 116(1), 1-31.

Gray, C., \& Behan, S. (2005). Current and predicted staffing patterns in post-primary 
schools: The perception and experience of school principals. Oxford Review of Education, 31(3), 443-458.

Hallinger, P. (2003). Leading educational change: Reflections on the practice of instructional and transformational leadership. Cambridge Journal of Education, 33(3), 329-352.

Hallinger, P., Bickman, L., \& Davis, K. (1996). School context, principal leadership, and student reading achievement. The Elementary School Journal, 96(5), 527549.

Hallinger, P., \& Heck, R. H. (2011) Exploring the journey of school improvement: Classifying and analyzing patterns of change in school improvement processes and learning outcomes. School Effectiveness and School Improvement, 22(1), $1-27$.

Hallinger, P., \& Murphy, J. (1985). Assessing the instructional management behavior of principals. The Elementary School Journal, 86(2), 217-247.

Hallinger, P., \& Murphy, J. F. (1986). The social context of effective schools. American Journal of Education, 94(3), 328-355.

Hambrick, D. C., \& Finkelstein, S. (1987). Managerial discretion: A bridge between polar views of organizational outcomes. Research in Organizational Behavior, 9, 369-406.

Heck, R. H. (1992). Principals' instructional leadership and school performance: Implications for policy development. Educational Evaluation and Policy Analysis, 14(1), 21-34.

Heck, R. H., \& Hallinger, P. (2010). Collaborative leadership effects on school improvement: Integrating unidirectional- and reciprocal-effects models. The Elementary School Journal, 111(2), 226-252. 
Heck, R. H., \& Hallinger, P. (2014). Modeling the longitudinal effects of school leadership on teaching and learning. Journal of Educational Administration, 52(5), 653-681.

Heck, R. H., \& Marcoulides, G. A. (1996). School culture and performance: Testing the invariance of an organizational model. School Effectiveness and School Improvement, 7(1), 76-95.

Hendriks, M. A., \& Scheerens, J. (2013). School leadership effects revisited: A review of empirical studies guided by indirect-effect models. School Leadership \& Management, 33(4), 373-394.

Hitt, D. H., \& Tucker, P. D. (2015). Systematic review of key leader practices found to influence student achievement: A unified framework. Review of Educational Research, 1-39. DOI: 10.3102/0034654315614911

Klar, H. W., \& Brewer, C. A. (2013). Successful leadership in high-needs schools: An examination of core leadership practices enacted in challenging contexts. Educational Administration Quarterly, 49, 768-808.

Ladd, H. F., \& Fiske, E. B. (2003). Does competition improve teaching and learning? Evidence from New Zealand. Educational Evaluation and Policy Analysis, 25(1), 97-112.

Latham, E. A., \& Locke, G. P. (2006). New directions in goal-setting theory. Current Directions in Psychological Science, 15, 265-268.

Lee, M., Walker, A., \& Chui, Y. L. (2012). Contrasting effects of instructional leadership practices on student learning in a high accountability context. Journal of Educational Administration, 50(5), 586-611.

Leithwood, K. (2012). Ontario Leadership Framework with a discussion of the 
Leadership foundations. Ottawa, Ontario, Canada: Institute for Education Leadership, OISE.

Leithwood, K., Day, C., Sammons, P., Harris, A., \& Hopkins, D. (2006). Seven strong claims about school leadership. Nottingham, UK: National College of School Leadership.

Leithwood, K., \& Jantzi, D. (2008). Linking leadership to student learning: The contribution of leader efficacy. Educational Administration Quarterly, 44, 496-528.

Leithwood, K., Jantzi, D., \& McElheron-Hopkins, C. (2006). The development and testing of a school improvement model. School Effectiveness and School Improvement, 17(4), 441-464.

Leithwood, K., Patten, S., \& Jantzi, D. (2010). Testing a conception of how school leadership influences student learning. Educational Administration Quarterly, 46, 671-706.

Leithwood, K. A., \& Stager, M. (1989). Expertise in principals' problem solving. Educational Administration Quarterly, 25(2), 126-161.

Liu, H., van Damme, J., Gielen, S., \& van den Noortgate, W. (2015). School processes mediate school compositional effects: Model specification and estimation. British Educational Research Journal, 41(3), 423-447.

Louis, K. S., Dretzke, B., \& Wahlstrom, K. (2010). How does leadership affect student achievement? Results from a national US survey. School Effectiveness and School Improvement, 21(3), 315-336.

Louis, K.S., \& Robinson, V. M. (2012). External mandates and instructional leadership: School leaders as mediating agents. Journal of Educational Administration, 50(5), $629-665$. 
Martin, J. (1992). Cultures in organizations: Three perspectives. New York, NY: Oxford University Press.

Maslow, A. H. (1943). A theory of human motivation. Psychological Review, 50, $370-396$.

May, H., Huff, J., \& Goldring, E. (2012). A longitudinal study of principals' activities and student performance. School Effectiveness and School Improvement, 23(4), 417-439.

McLaughlin, M. W., \& Talbert, J. E. (2007). Building professional learning communities in high schools: Challenges and promising practices. In L. Stoll \& K. S. Louis (Eds.), Professional learning communities: Divergence, depth and dilemmas (pp. 151-165). Berkshire, UK: Open University Press.

Menzias, S. J. (1995). Using institutional theory to understand for-profit sectors. In W. R. Scott \& S. M. Christensen (Eds.), The institutional construction of organizations (pp. 164-198). Thousand Oaks, CA: Sage.

Meyer, J. W., \& Scott, W. R. (1992). Centralization and the legitimacy problems of local government. In J. W. Meyer \& W. R. Scott (Eds.), Organizational environments: Ritual and rationality ( $2^{\text {nd }}$ ed.) (pp. 199-215). Newbury Park, CA: Sage.

Mourshed, M., Chijioke, C., \& Barber, M. (2010). How the world's most improved school systems keep getting better. Retrieved from http://ssomckinsey.darbyfilms.com/reports/EducationBookNov23.pdf

Murphy, J. (2015). Creating communities of professionalism: Addressing cultural and structural barriers. Journal of Educational Administration, 53(2), 154 - 176.

Murphy, J., \& Torre, D. (2015). Vision: Essential scaffolding. Educational Management Administration \& Leadership, 43(2), 177-197. 
Muthen, B. O. (2001). Latent variable mixture modeling. In G. A. Marcoulides \& R. E. Schumacker (Eds.), New developments and techniques in structural equation modeling (pp. 1-33). Mahwah, NJ: Lawrence Erlbaum.

Newmann, F. M., King, M. B., \& Youngs, P. (2000). Professional development that addresses school capacity: Lessons from urban elementary schools. American Journal of Education, 108(4), 259-299.

OECD. (2013). PISA 2012 results in focus: What 15-year-olds know and what they can do with what they know. Retrieved from http://www.oecd.org/pisa/keyfindings/pisa-2012-results-overview.pdf

Opfer, V. D., \& Pedder, D. (2011). Conceptualizing teacher professional learning. Review of Educational Research, 81(3), 376-407.

Ostroff, C., Kinicki, A. J., \& Tamkins, M. M. (2003). Organizational climate and culture. In W. C. Borman, D. R. Ilgen, \& R. J. Klimoski (Eds.), Comprehensive handbook of psychology: Industrial and organizational psychology (Vol. 12) (pp. 565-594). New York, NY: John Wiley.

Raudenbush, S. W., \& Bryk, A. S. (2002). Hierarchical linear models: Applications and data analysis methods ( $\left.2^{\text {nd }} e d.\right)$. Thousand Oaks, CA: Sage.

Robinson, V. M. J., Lloyd, C. A., \& Rowe, K. J. (2008). The impact of leadership on student outcomes: An analysis of the differential effects of leadership types. Educational Administration Quarterly, 44(5), 635-674.

Ross, J. A., \& Gray, P. (2006). School leadership and student achievement. The mediating effects of teacher beliefs. Canadian Journal of Education, 29(3), 798-822.

Rubie-Davies, C. M. (2007). Classroom interactions: Exploring the practices of high- 
and low-expectations teachers. British Journal of Educational Psychology, 77, 289-306.

Scott, W. R. (1994). Institutional analysis: Variance and process theory approaches Employee training: The expansion of organizational citizenship. In W. R. Scott, J. W. Meyer, \& Associates (Eds.), Institutional environments and organizations: Structural complexity and individualism (pp. 81-99). Thousand Oaks, CA: Sage.

Spillane, J. P. (2006). Distributed leadership. San Francisco, CA: Jossey-Bass.

Suchman, M. C. (1995). Managing legitimacy: Strategic and institutional approaches. Academy of Management Review, 20(3), 571-610.

Sun, J., \& Leithwood, K. (2015). Direction-setting school leadership practices: A meta-analytical review of evidence about their influence. School Effectiveness and School Improvement, 26(4), 499-523.

Supovitz, J., Sirinides, P., \& May, H. (2010). How principals and peers influence teaching and learning. Educational Administration Quarterly, 46, 31-46.

Tan, C. Y. (2013). Influence of contextual challenges and constraints on learningcentered leadership. School Effectiveness and School Improvement, 25(3), 451-468.

Ten Bruggencate, G., Luyten, G. H., \& Scheerens, J. (2010). Quantitative analysis of international data: Exploring indirect effect models of school leadership. Enschede: University of Twente.

Ten Bruggencate, G., Luyten, H., Scheerens, J., \& Sleegers, P. (2012). Modeling the influence of school leaders on student achievement: How can school leaders make a difference? Educational Administration Quarterly, 48(4), 699-732.

Timperley, H. (2011). Knowledge and the leadership of learning. Leadership and 
Policy in Schools, 10, 145-170.

Tschannen-moran, M. (2009). Fostering teacher professionalism in schools the role of leadership orientation and trust. Educational Administration Quarterly, 45, $217-247$.

Urick, A., \& Bowers, A. (2014). What are the different types of principals across the United States? A latent class analysis of principal perceptions pf leadership. Educational Administration Quarterly, 50, 96-134.

Valentine, J. C., DuBois, D. L., \& Cooper, H. (2004). The relation between selfbeliefs and academic achievement: A meta-analytic review. Educational Psychologist, 39(2), 111-133.

Warwas, J. (2015). Principals' leadership behaviour: Values-based, contingent or both? Journal of Educational Administration, 53(3), 310 - 334.

Wasserman, N., Nohria, N., \& Anand, B. (2010). When does leadership matter? A contingent opportunities view of CEO leadership. In N. Nohria \& R. Khurana (Eds.), Handbook of leadership theory and practice: An HBS centennial colloquium on advancing leadership (pp. 27-63). Boston, MA: Harvard Business Press.

Wahlstrom, K., \& Louis, K. S. (2008). How teachers experience principal leadership: The roles of professional community, trust, efficacy and shared responsibility. Educational Administration Quarterly, 44, 458-495.

Willms, J. D. (2010). School composition and contextual effects on student outcomes. Teachers College Record, 112(4), 1008-1037. 
Table 1. Summary of means and standard deviations for variables.

\begin{tabular}{|c|c|c|c|}
\hline & & $M(S D)$ & \\
\hline Variable & $\begin{array}{l}\text { Disadvantaged } \\
\qquad(n=24,882)\end{array}$ & $\begin{array}{c}\text { Average } \\
(n=179,836)\end{array}$ & $\begin{array}{l}\text { Privileged } \\
(n=49,757)\end{array}$ \\
\hline MathPV1 & $428.86(90.58)$ & 490.93(92.67) & $510.55(92.70)$ \\
\hline MathPV2 & $428.95(90.16)$ & 490.93(92.76) & $510.67(92.72)$ \\
\hline MathPV3 & $429.23(90.16)$ & 490.97(92.77) & $510.54(92.73)$ \\
\hline MathPV4 & $429.16(89.89)$ & 490.99(92.84) & $510.45(92.61)$ \\
\hline MathPV5 & $428.90(90.34)$ & 491.05(92.84) & $510.68(92.74)$ \\
\hline PInstruct & $-0.08(1.01)$ & $-0.02(1.00)$ & $0.12(1.08)$ \\
\hline PDistribute & $0.13(1.12)$ & $-0.00(0.98)$ & $0.06(1.04)$ \\
\hline PGoals & $0.13(1.01)$ & $0.02(0.99)$ & $0.15(1.08)$ \\
\hline PProblemSolve & $0.13(0.98)$ & $0.07(0.96)$ & $0.08(1.04)$ \\
\hline TrMorale & $-0.35(1.01)$ & $-0.11(0.96)$ & $0.25(0.96)$ \\
\hline TrAutonomy & $-0.49(0.99)$ & $0.02(0.94)$ & $0.04(0.94)$ \\
\hline TrFocus & $-0.12(1.03)$ & $-0.16(0.99)$ & $-0.01(1.05)$ \\
\hline SES & $-1.11(1.20)$ & $-0.02(1.00)$ & $0.23(0.92)$ \\
\hline ShortTr & $1.02(1.00)$ & $-0.01(0.93)$ & $-0.55(0.78)$ \\
\hline QualEdRes & $-1.67(0.72)$ & $-0.19(0.55)$ & $1.52(0.53)$ \\
\hline QualInf & $-1.36(0.85)$ & $-0.13(0.86)$ & $0.90(0.65)$ \\
\hline ParentExp & $1.76(0.69)$ & $1.85(0.71)$ & $1.97(0.76)$ \\
\hline
\end{tabular}




\section{MODERATED LEADERSHIP EFFECTS}

Table 2. Mixture modeling.

\begin{tabular}{lcccc}
\hline & Akaike (AIC) & Baysesian (BIC) & $\begin{array}{c}\text { Sample size } \\
\text { adjusted BIC }\end{array}$ & Entrophy \\
\hline 1-class solution & $3,698,076.02$ & $3,698,190.94$ & $3,698,155.98$ & - \\
2-class solution & $3,599,440.73$ & $3,599,628.77$ & $3,599,571.57$ & 0.59 \\
3-class solution & $3,558,339.97$ & $3,558,601.15$ & $3,558,521.70$ & 0.78 \\
4-class solution & $3,535,751.30$ & $3,536,085.61$ & $3,535,983.91$ & 0.71 \\
\hline
\end{tabular}




\section{MODERATED LEADERSHIP EFFECTS}

Table 3. Fixed effects estimates (top) and variance-covariance estimates (bottom) for models of the predictors of MathPV1.

\begin{tabular}{|c|c|c|c|c|c|c|c|c|c|}
\hline \multirow[b]{2}{*}{ Parameter } & \multirow[b]{2}{*}{ Model 1a } & \multirow{2}{*}{$\begin{array}{c}\text { Disadvantaged } \\
\text { Model 1b }\end{array}$} & \multirow[b]{2}{*}{ Model 1c } & \multirow[b]{2}{*}{ Model 2a } & \multirow{2}{*}{$\begin{array}{l}\text { Average } \\
\text { Model 2b }\end{array}$} & \multirow[b]{2}{*}{ Model 2c } & \multirow[b]{2}{*}{ Model 3a } & \multirow{2}{*}{$\begin{array}{c}\text { Privileged } \\
\text { Model 3b }\end{array}$} & \multirow[b]{2}{*}{ Model 3c } \\
\hline & & & & & & & & & \\
\hline \multicolumn{10}{|l|}{ Fixed effects } \\
\hline Intercept & $421.33 * *(1.69)$ & $423.90 * *(1.73)$ & $432.10 * *(1.81)$ & $484.33 * *(0.72)$ & $484.09 * *(0.71)$ & $484.13 * *(0.68)$ & $506.23 * *(1.32)$ & $505.67 * *(1.31)$ & $503.52 * *(1.33)$ \\
\hline \multicolumn{10}{|l|}{ Level 2} \\
\hline PInstruct & & $11.74 * *(2.62)$ & $8.30 * *(2.52)$ & & $7.12 * *(1.11)$ & $5.06 * *(1.08)$ & & $4.98 * *(1.85)$ & $3.35(1.81)$ \\
\hline PDistribute & & $-5.25 *(2.14)$ & $-5.21 *(2.05)$ & & $0.90(0.99)$ & $0.32(0.96)$ & & $2.38(1.78)$ & $1.70(1.74)$ \\
\hline PGoals & & $-9.34 * *(2.47)$ & $-5.27 *(2.40)$ & & $-6.46 * *(1.03)$ & $-5.75 * *(0.99)$ & & $-4.94 * *(1.84)$ & $-4.28 *(1.80)$ \\
\hline PProblemSolve & & $-3.36(2.28)$ & $-2.97(2.18)$ & & $-11.45^{* *}(0.92)$ & $-9.31 * *(0.90)$ & & $-12.04 * *(1.52)$ & $-9.70 * *(1.51)$ \\
\hline TrMorale & & & $7.97 * *(1.75)$ & & & $11.40 * *(0.76)$ & & & $11.95^{* *}(1.38)$ \\
\hline TrAutonomy & & & $15.64 * *(1.62)$ & & & $9.10^{* *}(0.73)$ & & & $3.19 *(1.36)$ \\
\hline TrFocus & & & $-12.09 * *(1.77)$ & & & $-11.40 * *(0.73)$ & & & $-10.54 * *(1.26)$ \\
\hline
\end{tabular}

Random parameters

Level 1

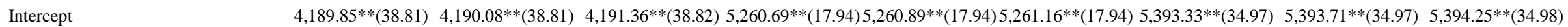

Level 2

Intercept

$3,981.44 * *(160.87) 3,883.89 * *(157.58) 3,468.89 * *(143.10) 3,575.74 * *(64.32) 3,451.66 * *(62.31) 3,196.75 * *(58.11) 3,391.54 * *(114.40) 3,252.97 * *(110.33) 3,056.72 * *(104.44)$

$\%$ Level 1 variance

$\begin{array}{lllllllll}51.28 & 51.90 & 54.72 & 59.53 & 60.38 & 62.20 & 61.39 & 62.38 & 63.83\end{array}$

$\%$ Level 2 variance

$\begin{array}{lll}48.72 & 48.10 & 45.28\end{array}$

$\begin{array}{lll}40.47 & 39.62 & 37.80\end{array}$

$38.61 \quad 37.62$

36.17

$\%$ Reduction in Level 2 variance

$\begin{array}{llll}2.45 & 12.87 & 3.47 & 10.60\end{array}$

4.09

9.87

-2 Restricted log likelihood

$282,004.75$

$281,954.57$

$281,795.56$

$2,071,612.58$

$2,071,363.47$

$2,070,835.86$

$574,376.98$

$574,284.02$

$574,157.83$

Note: Standard errors in parentheses.

$* * p<.01 . * p<.05$ 


\section{MODERATED LEADERSHIP EFFECTS}

Table 4. Fixed effects estimates (top) and variance-covariance estimates (bottom) for models of the predictors of MathPV2.

\begin{tabular}{|c|c|c|c|c|c|c|c|c|c|}
\hline \multirow[b]{2}{*}{ Parameter } & \multirow[b]{2}{*}{ Model 1a } & \multirow{2}{*}{$\begin{array}{c}\text { Disadvantaged } \\
\text { Model 1b }\end{array}$} & \multirow[b]{2}{*}{ Model 1c } & \multirow[b]{2}{*}{ Model 2a } & \multirow{2}{*}{$\begin{array}{l}\text { Average } \\
\text { Model 2b }\end{array}$} & \multirow[b]{2}{*}{ Model 2c } & \multirow[b]{2}{*}{ Model 3a } & Privileged & \multirow[b]{2}{*}{ Model 3c } \\
\hline & & & & & & & & Model 3b & \\
\hline \multicolumn{10}{|l|}{ Fixed effects } \\
\hline Intercept & $421.54 * *(1.69)$ & $423.99 * *(1.74)$ & $432.11 * *(1.81)$ & $484.27 * *(0.72)$ & $484.04 * *(0.71)$ & $484.06 * *(0.68)$ & $506.32 * *(1.32)$ & $505.74 * *(1.31)$ & $503.69 * *(1.33)$ \\
\hline \multicolumn{10}{|l|}{ Level 2} \\
\hline PInstruct & & $11.22 * *(2.62)$ & $7.79 * *(2.52)$ & & $7.00 * *(1.11)$ & $4.94 * *(1.08)$ & & $5.19 * *(1.85)$ & $3.63 *(1.81)$ \\
\hline PDistribute & & $-5.01 *(2.14)$ & $-4.95 *(2.05)$ & & $1.16(0.99)$ & $0.57(0.96)$ & & $2.26(1.78)$ & $1.63(1.74)$ \\
\hline PGoals & & $-8.87 * *(2.47)$ & $-4.72 *(2.40)$ & & $-6.52 * *(1.03)$ & $-5.80^{* *}(0.99)$ & & $-5.05 * *(1.84)$ & $-4.39 *(1.80)$ \\
\hline PProblemSolve & & $-3.19(2.28)$ & $-2.83(2.18)$ & & $-11.24 * *(0.92)$ & $-9.11^{* *}(0.90)$ & & $-12.18 * *(1.52)$ & $-9.93^{* *}(1.51)$ \\
\hline TrMorale & & & $7.77 * *(1.75)$ & & & $11.33^{* *}(0.76)$ & & & $11.60 * *(1.38)$ \\
\hline IrAutonomy & & & $15.54 * *(1.62)$ & & & $9.18 * *(0.73)$ & & & $2.96 *(1.36)$ \\
\hline TrFocus & & & $-12.40 * *(1.77)$ & & & $-11.39 * *(0.73)$ & & & $-10.50 * *(1.26)$ \\
\hline \multicolumn{10}{|l|}{ Random parameters } \\
\hline \multicolumn{10}{|l|}{ Level 1} \\
\hline Intercept & $4,174.23 * *(38.67)$ & $4,174.54 * *(38.67)$ & $4,175.82 * *(38.69)$ & $5,273.18 * *(17.98)$ & $5,273.40 * *(17.98)$ & $5,273.62 * *(17.98)$ & $5,404.13 * *(35.04)$ & $5,404.57 * *(35.04)$ & $5,405.23 * *(35.05)$ \\
\hline \multicolumn{10}{|c|}{ - } \\
\hline Intercept & $3,977.14 * *(161.05)$ & $3,888.37 * *(158.12)$ & $3,471.31 * *(143.53)$ & $3,570.80 * *(64.19)$ & $3,451.02 * *(62.25)$ & $3,196.58 * *(58.06)$ & $3,394.80 * *(114.62)$ & $3,251.27 * *(110.41)$ & $3,061.03 * *(104.73)$ \\
\hline$\%$ Level 1 variance & 51.21 & 51.77 & 54.61 & 59.62 & 60.44 & 62.26 & 61.42 & 62.44 & 63.84 \\
\hline \% Level 2 variance & 48.79 & 48.23 & 45.39 & 40.38 & 39.56 & 37.74 & 38.58 & 37.56 & 36.16 \\
\hline \multicolumn{10}{|c|}{$\begin{array}{l}\% \text { Reduction in Level } 2 \\
\text { variance compared to }\end{array}$} \\
\hline Model a & & 2.23 & 12.72 & & 3.35 & 10.48 & & 4.23 & 9.83 \\
\hline-2 Restricted log & $281,915.52$ & $281,868.83$ & $281,709.15$ & $2,072,013.15$ & $2,071,772.80$ & $2,071,244.56$ & $574,474.49$ & $574,379.20$ & $574,257.74$ \\
\hline likelihood & & & & & & & & & \\
\hline
\end{tabular}

Note: Standard errors in parentheses.

$* * p<.01 . * p<.05$ 


\section{MODERATED LEADERSHIP EFFECTS}

Table 5. Fixed effects estimates (top) and variance-covariance estimates (bottom) for models of the predictors of MathPV3.

\begin{tabular}{|c|c|c|c|c|c|c|c|c|c|}
\hline \multirow[b]{2}{*}{ Parameter } & \multirow[b]{2}{*}{ Model 1a } & \multirow{2}{*}{$\begin{array}{c}\text { Disadvantaged } \\
\text { Model 1b }\end{array}$} & \multirow[b]{2}{*}{ Model 1c } & \multirow[b]{2}{*}{ Model 2a } & \multirow{2}{*}{\begin{tabular}{|c|} 
Average \\
Model $2 \mathrm{~b}$
\end{tabular}} & \multirow[b]{2}{*}{ Model 2c } & \multirow[b]{2}{*}{ Model 3a } & Privileged & \multirow[b]{2}{*}{ Model 3c } \\
\hline & & & & & & & & Model 3b & \\
\hline \multicolumn{10}{|l|}{ Fixed effects } \\
\hline Intercept & $421.96 * *(1.69)$ & $424.49 * *(1.73)$ & $432.46 * *(1.81)$ & $484.40 * *(0.72)$ & $484.16^{* *}(0.71)$ & $484.19 * *(0.68)$ & $506.27 * *(1.32)$ & $505.70 * *(1.31)$ & $503.64 * *(1.33)$ \\
\hline \multicolumn{10}{|l|}{ Level 2} \\
\hline PInstruct & & $11.67 * *(2.61)$ & $8.33 * *(2.52)$ & & $6.88 * *(1.11)$ & $4.80 * *(1.08)$ & & $5.06 * *(1.85)$ & $3.49(1.81)$ \\
\hline PDistribute & & $-5.42 *(2.14)$ & $-5.37 * *(2.04)$ & & $1.11(0.99)$ & $0.53(0.96)$ & & $2.17(1.78)$ & $1.51(1.74)$ \\
\hline PGoals & & $-8.93 * *(2.47)$ & $-4.87 *(2.40)$ & & $-6.35 * *(1.03)$ & $-5.62 * *(0.99)$ & & $-4.86^{* *}(1.84)$ & $-4.21 *(1.80)$ \\
\hline PProblemsolve & & $-3.08(2.27)$ & $-2.75(2.17)$ & & $-11.44 * *(0.92)$ & $-9.28 * *(0.90)$ & & $-12.00 * *(1.52)$ & $-9.70 * *(1.51)$ \\
\hline irivorale & & & $7.78 * *(1.75)$ & & & $11.41 * *(0.76)$ & & & $11.56 * *(1.38)$ \\
\hline IrAutonomy & & & $15.15^{* *}(1.62)$ & & & $9.29 * *(0.73)$ & & & $3.37 *(1.36)$ \\
\hline IIrocus & & & $-12.28 * *(1.77)$ & & & $-11.49 * *(0.73)$ & & & $-10.62 * *(1.26)$ \\
\hline \multicolumn{10}{|l|}{ Random parameters } \\
\hline \multicolumn{10}{|l|}{ Level 1} \\
\hline $\begin{array}{l}\text { Intercept } \\
\text { Level } 2\end{array}$ & $4,182.98 * *(38.75)$ & $4,183.39 * *(38.75)$ & $4,184.63 * *(38.77)$ & $5,271.30 * *(17.97)$ & $5,271.52 * *(17.97)$ & $5,271.73 * *(17.98)$ & $5,417.72 * *(35.13)$ & $5,418.20 * *(35.14)$ & $5,418.92 * *(35.14)$ \\
\hline Intercept & $3,959.98 * *(160.39)$ & $3,864.80 * *(157.25)$ & $3,463.38 * *(143.23)$ & $3,577.18 * *(64.30)$ & $3,454.54 * *(62.32)$ & $3,195.58 * *(58.05)$ & $3,389.74 * *(114.62)$ & $3,250.38 * *(110.53)$ & $3,054.92 * *(104.70)$ \\
\hline$\%$ Level 1 variance & 51.37 & 51.98 & 54.72 & 59.57 & 60.41 & 62.26 & 61.51 & 62.50 & 63.95 \\
\hline$\%$ Level 2 variance & 48.63 & 48.02 & 45.28 & 40.43 & 39.59 & 37.74 & 38.49 & 37.50 & 36.05 \\
\hline \multicolumn{10}{|l|}{$\%$ Reduction in Level 2} \\
\hline variance compared to & & 2.40 & 12.54 & & 3.43 & 10.67 & & 4.11 & 9.88 \\
\hline \multicolumn{10}{|l|}{ Model a } \\
\hline-2 Restricted log & $281,958.74$ & $281,910.25$ & $281,755.63$ & $2,071,963.63$ & $2,071,718.48$ & $2,071,180.63$ & $574,591.63$ & $574,499.04$ & $574,374.85$ \\
\hline likelihood & & & & & & & & & \\
\hline
\end{tabular}

Note: Standard errors in parentheses.

$* * p<.01 . * p<.05$ 


\section{MODERATED LEADERSHIP EFFECTS}

Table 6. Fixed effects estimates (top) and variance-covariance estimates (bottom) for models of the predictors of MathPV4.

\begin{tabular}{|c|c|c|c|c|c|c|c|c|c|}
\hline \multirow[b]{2}{*}{ Parameter } & \multirow[b]{2}{*}{ Model 1a } & \multirow{2}{*}{$\begin{array}{c}\text { Disadvantaged } \\
\text { Model } 1 \mathrm{~b}\end{array}$} & \multirow[b]{2}{*}{ Model 1c } & \multirow[b]{2}{*}{ Model 2a } & \multirow{2}{*}{$\begin{array}{l}\text { Average } \\
\text { Model } 2 \mathrm{~b}\end{array}$} & \multirow[b]{2}{*}{ Model 2c } & \multirow[b]{2}{*}{ Model 3a } & Privileged & \multirow[b]{2}{*}{ Model 3c } \\
\hline & & & & & & & & Model 3b & \\
\hline \multicolumn{10}{|l|}{ Fixed effects } \\
\hline Intercept & $422.02 * *(1.69)$ & $424.56 * *(1.73)$ & $432.50 * *(1.81)$ & $484.35 * *(0.72)$ & $484.12 * *(0.71)$ & $484.15^{* *}(0.68)$ & $506.12 * *(1.31)$ & $505.55 * *(1.31)$ & $503.53 * *(1.33)$ \\
\hline \multicolumn{10}{|l|}{ Level 2} \\
\hline PInstruct & & $11.66 * *(2.61)$ & $8.35^{* *}(2.52)$ & & $6.95 * *(1.11)$ & $4.86^{* *}(1.08)$ & & $4.85^{* *}(1.84)$ & $3.30(1.81)$ \\
\hline PDistribute & & $-5.21 *(2.14)$ & $-5.14 *(2.04)$ & & $1.22(0.99)$ & $0.63(0.96)$ & & $2.68(1.77)$ & $2.03(1.73)$ \\
\hline PGoals & & $-9.46 * *(2.46)$ & $-5.38 *(2.39)$ & & $-6.40 * *(1.03)$ & $-5.69 * *(0.99)$ & & $-4.83 * *(1.84)$ & $-4.16 *(1.79)$ \\
\hline PProblemsolve & & $-2.77(2.27)$ & $-2.44(2.17)$ & & $-11.36 * *(0.92)$ & $-9.19 * *(0.90)$ & & $-12.18 * *(1.52)$ & $-9.87 * *(1.51)$ \\
\hline MTMiorale & & & $7.92 * *(1.75)$ & & & $11.52 * *(0.76)$ & & & $11.54 * *(1.38)$ \\
\hline TrAutonomy & & & $14.99 * *(1.62)$ & & & $9.30^{* *}(0.73)$ & & & $3.38 *(1.35)$ \\
\hline TrFocus & & & $-12.59 * *(1.77)$ & & & $-11.48 * *(0.73)$ & & & $-10.86 * *(1.26)$ \\
\hline \multicolumn{10}{|l|}{ Random parameters } \\
\hline \multicolumn{10}{|l|}{ Level 1} \\
\hline Intercept & $4,120.85 * *(38.17)$ & $4,121.13^{* *}(38.18)$ & $4,122.49 * *(38.19)$ & $5,286.94 * *(18.03)$ & $5,287.17 * *(18.03)$ & $5,287.36^{* *}(18.03)$ & $5,401.29 * *(35.02)$ & $5,401.70 * *(35.03)$ & $5,402.30 * *(35.03)$ \\
\hline \multicolumn{10}{|c|}{ 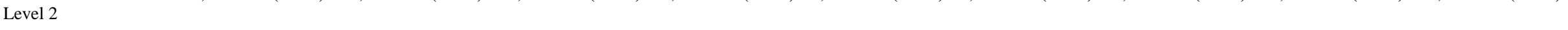 } \\
\hline Intercept & $3,966.42 * *(160.35)$ & $3,871.79 * *(157.18)$ & $3,466.27 * *(143.07)$ & $3,587.19 * *(64.56)$ & $3,466.57 * *(62.61)$ & $3,206.33^{* *}(58.31)$ & $3,383.42 * *(114.35)$ & $3,244.11 * *(110.25)$ & $3,046.40 * *(104.32)$ \\
\hline \% Level 1 variance & 50.95 & 51.56 & 54.32 & 59.58 & 60.40 & 62.25 & 61.49 & 62.48 & 63.94 \\
\hline \% Level 2 variance & 49.05 & 48.44 & 45.68 & 40.42 & 39.60 & 37.75 & 38.51 & 37.52 & 36.06 \\
\hline \multicolumn{10}{|l|}{ \% Reduction in Level 2} \\
\hline variance compared to & & 2.39 & 12.61 & & 3.36 & 10.62 & & 4.12 & 9.96 \\
\hline \multicolumn{10}{|l|}{ Model a } \\
\hline-2 Restricted log & $281,609.39$ & $281,560.37$ & $281,404.91$ & $2,072,495.29$ & $2,072,254.93$ & $2,071,715.57$ & $574,442.82$ & $574,349.51$ & $574,222.56$ \\
\hline likelihood & & & & & & & & & \\
\hline
\end{tabular}

Note: Standard errors in parentheses.

$* * p<.01 . * p<.05$ 


\section{MODERATED LEADERSHIP EFFECTS}

Table 7. Fixed effects estimates (top) and variance-covariance estimates (bottom) for models of the predictors of MathPV5.

\begin{tabular}{|c|c|c|c|c|c|c|c|c|c|}
\hline \multirow[b]{2}{*}{ Parameter } & \multirow[b]{2}{*}{ Model 1a } & \multirow{2}{*}{$\begin{array}{c}\text { Disadvantaged } \\
\text { Model } 1 \mathrm{~b}\end{array}$} & \multirow[b]{2}{*}{ Model 1c } & \multirow[b]{2}{*}{ Model 2a } & \multirow{2}{*}{$\begin{array}{l}\text { Average } \\
\text { Model 2b }\end{array}$} & \multirow[b]{2}{*}{ Model 2c } & \multirow[b]{2}{*}{ Model 3a } & Privileged & \multirow[b]{2}{*}{ Model 3c } \\
\hline & & & & & & & & Model 3b & \\
\hline \multicolumn{10}{|l|}{ Fixed effects } \\
\hline Intercept & $421.62 * *(1.70)$ & $424.12 * *(1.74)$ & $432.00 * *(1.82)$ & $484.44 * *(0.72)$ & $484.20 * *(0.71)$ & $484.23 * *(0.68)$ & $506.39 * *(1.31)$ & $505.78 * *(1.31)$ & $503.76 * *(1.33)$ \\
\hline \multicolumn{10}{|l|}{ Level 2} \\
\hline PInstruct & & $11.56 * *(2.62)$ & $8.20 * *(2.53)$ & & $6.94 * *(1.11)$ & $4.85^{* *}(1.08)$ & & $5.27 * *(1.84)$ & $3.72 *(1.81)$ \\
\hline PDistribute & & $-4.51 *(2.14)$ & $-4.43 *(2.05)$ & & $1.23(0.99)$ & $0.64(0.96)$ & & $2.20(1.77)$ & $1.55(1.74)$ \\
\hline PGoals & & $-9.78 * *(2.47)$ & $-5.69 *(2.40)$ & & $-6.48 * *(1.03)$ & $-5.76 * *(0.99)$ & & $-4.81 * *(1.84)$ & $-4.15 *(1.79)$ \\
\hline PProdemsolve & & $-3.39(2.28)$ & $-3.08(2.18)$ & & $-11.38 * *(0.92)$ & $-9.21 * *(0.90)$ & & $-12.15 * *(1.52)$ & $-9.87 * *(1.51)$ \\
\hline MTMiorale & & & $7.34 * *(1.75)$ & & & $11.42 * *(0.76)$ & & & $11.44 * *(1.38)$ \\
\hline TrAutonomy & & & $15.26 * *(1.62)$ & & & $9.31 * *(0.73)$ & & & $3.30 *(1.35)$ \\
\hline TrFocus & & & $-12.04 * *(1.77)$ & & & $-11.40 * *(0.73)$ & & & $-10.62 * *(1.26)$ \\
\hline \multicolumn{10}{|l|}{ Random parameters } \\
\hline \multicolumn{10}{|l|}{ Level 1} \\
\hline Intercept & $4,172.94 * *(38.65)$ & $4,173.29 * *(38.66)$ & $4,174.79 * *(38.68)$ & $5,282.01 * *(18.01)$ & $5,282.23 * *(18.01)$ & $5,282.43 * *(18.01)$ & $5,416.62 * *(35.12)$ & $5,417.00 * *(35.12)$ & $5,417.58 * *(35.13)$ \\
\hline \multicolumn{10}{|c|}{ 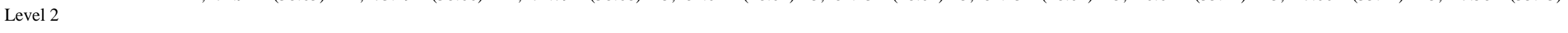 } \\
\hline Intercept & $3,987.67 * *(161.23)$ & $3,891.38 * *(158.03)$ & $3,490.23 * *(144.14)$ & $3,584.34 * *(64.48)$ & $3,462.66 * *(62.52)$ & $3,204.64 * *(58.25)$ & $3,380.69 * *(114.08)$ & $3,241.75^{* *}(110.00)$ & $3,050.65^{* *}(104.29)$ \\
\hline \% Level 1 variance & 51.14 & 51.75 & 54.47 & 59.57 & 60.40 & 62.24 & 61.57 & 62.56 & 63.98 \\
\hline \% Level 2 variance & 48.86 & 48.25 & 45.53 & 40.43 & 39.60 & 37.76 & 38.43 & 37.44 & 36.02 \\
\hline \multicolumn{10}{|l|}{ \% Reduction in Level 2} \\
\hline variance compared to & & 2.41 & 12.47 & & 3.39 & 10.59 & & 4.11 & 9.76 \\
\hline \multicolumn{10}{|l|}{ Model a } \\
\hline-2 Restricted log & $281,911.94$ & $281,862.89$ & $281,710.73$ & $2,072,328.49$ & $2,072,085.46$ & $2,071,550.85$ & $574,576.69$ & $574,483.33$ & $574,360.33$ \\
\hline likelihood & & & & & & & & & \\
\hline
\end{tabular}

Note: Standard errors in parentheses.

$* * p<.01 . * p<.05$ 